\title{
Infection Mitigation Efficacy of Photoactive Titania on Orthopedic Implant Materials
}

\author{
Abdul-Majeed Azad, ${ }^{1}$ Ryan Hershey, ${ }^{2}$ Asem Aboelzahab, ${ }^{3}$ and Vijay Goel ${ }^{4}$ \\ ${ }^{1}$ Department of Chemical Engineering, The University of Toledo, 2801 West Bancroft Street, Toledo, OH 43606-3390, USA \\ ${ }^{2}$ Vesuvius Research Center, 495 Emma Street, Bettsville, OH 44815, USA \\ ${ }^{3}$ Bioengineering Department, The University of Toledo, 2801 West Bancroft Street, Toledo, OH 43606-3390, USA \\ ${ }^{4}$ Departments of Bioengineering and Orthopedic Surgery, Health Science Campus, The University of Toledo, 2801 West Bancroft Street, \\ Toledo, OH 43606-3390, USA \\ Correspondence should be addressed to Abdul-Majeed Azad, abdul-majeed.azad@utoledo.edu
}

Received 1 September 2010; Accepted 29 December 2010

Academic Editor: Robert F. Ostrum

Copyright (C) 2011 Abdul-Majeed Azad et al. This is an open access article distributed under the Creative Commons Attribution License, which permits unrestricted use, distribution, and reproduction in any medium, provided the original work is properly cited.

\begin{abstract}
In order to impede infection and achieve accelerated wound healing in the postorthopaedic surgery patients, a simple and benign procedure for creating nanotubular or nanofibrillar structure of photoactive $\mathrm{TiO}_{2}$ on the surface of Ti plates and wires is described. The nanoscale $\mathrm{TiO}_{2}$ films on titanium were grown by hydrothermal processing in one case and by anodization in the presence of dilute mineral acids under mild and benign conditions in the other. Confocal microscopy results demonstrated at least $50 \%$ reduction in the population of $E$. coli colonies (concentration $2.15 \times 10^{7}$ cells $/ \mathrm{mL}$ ) on $\mathrm{TiO}_{2}$-coated implants upon an IR exposure of up to $30 \mathrm{~s}$; it required $\sim 20 \mathrm{~min}$ of exposure to UV beam for the same effect. These findings suggest the probability of eliminating wound infection during and after orthopedic surgical procedures by brief illumination of photoactive titania films on the implants with an IR beam.
\end{abstract}

\section{Introduction}

Disease-carrying pathogens in the body not only destroy healthy tissue but can eventually multiply and spread throughout the blood stream causing infection. Infections can be reduced and healing accelerated by using a nanotechnological approach with photoactive antimicrobial materials.

We recently described the fabrication of pure and doped titania nanofibers possessing optimal porosity and structure, and their photocatalytic antimicrobial activity towards E. coli [1]. With the objectivity of their ultimate application towards mitigation of wound infection and bone healing-the spinal injury in particular-experimental protocols were developed to create photoactive films of titanium dioxide (titania) on titanium substrates. Several methods were developed for creating nanostructured coating of titania on "commercial purity" titanium (cp Ti) coupons and implants. The methods included hydrothermal processing under different experimental conditions using various media. In one case, titanium coupons precoated with $\mathrm{TiO}_{2}$ films were also used. As another viable technique, anodization was also employed to create nanotubular structures on titanium plates and wires. Exposure of these implants coated with titania films to IR laser for up to $30 \mathrm{~s}$, demonstrated effective inhibition of E. coli growth, thus opening the possibility of using $\mathrm{Ti}$ implants coated with $\mathrm{TiO}_{2}$ nanocrystals or nanotubes as means of effective disinfectants for the prevention of major surgical site infections. The demonstration of the efficacy of IR light towards infection mitigation in terms of the biocidal activity of titania-coated implant material is the first of its kind.

\section{Materials and Methods}

Titanium — the basic material in implants — was used in two configurations: plates and wires. While plates are ideal for 
fixed geometry applications, it is anticipated that flexible wires would be a good way to induce healing in those orthopedic injuries where plates are difficult to be inserted. Wires can be folded, twisted, and configured to reach and stay in places where plates cannot. Another point of relevance that justifies using wires is the fact that the hip implants are coated with bead or wire geometry to provide surface for bone in-growth, thus, making antibacterial coatings on intricate yet flexible geometries such as wires valuable. With the same rationale, work is in progress using $\mathrm{Ti}$ mesh, and the results of this investigation would be reported elsewhere.

The desired coating on Ti substrates was prepared by using three methods: hydrothermal processing of $\mathrm{cp} \mathrm{Ti}$ coupons (from Alfa-Aesar, MA, and United Titanium Inc., Wooster, OH, USA), hydrothermal processing of $\mathrm{TiO}_{2}-$ coated cp Ti coupons (from Henkel Corporation, Madison Heights, MI, USA), and anodization of cp Ti coupons and cp Ti wires (Alfa-Aesar, MA, USA). In this study both plates and wires were $99.7 \%$ pure. One goal of the study was to optimize fabrication conditions which could be mimicked on the real-life Ti and Ti6Al4V implants. Another goal was to examine which of the two morphologies (nanofibrillar growth via hydrothermal processing versus nanotubular growth via anodization) has higher bactericidal propensity. The coupons were cut from $100 \mathrm{~mm} \times 100 \mathrm{~mm} \times 2 \mathrm{~mm} \mathrm{Ti}$ plates while the wire samples were $1.024 \mathrm{~mm}$ in diameter.

2.1. Hydrothermal Processing of cp Ti Plates. Hydrothermal processing is a homogeneous (for nanoparticles) or heterogeneous (for bulk materials) reaction in the presence of mineralizers under high-pressure and mild-temperature conditions in a closed system to dissolve and recrystallize materials that are slightly insoluble under normal conditions. Invariably, autoclaves are used for this purpose with suitable construction materials that could withstand temperatures up to $\sim 250-300^{\circ} \mathrm{C}$ and pressures up to $2000 \mathrm{psi}$. The technique offers the advantage of upscaled production without much difficulty or compromising the consistency and reproducibility.

In our case, the purpose of hydrothermal synthesis was to create titania films on the Ti substrates. It was carried out in a bench-top 1-L capacity autoclave (Autoclave Engineers, Erie, PA, USA). The 2-mm-thick cp Ti plate was cut into about $6 \mathrm{~mm} \times 6 \mathrm{~mm}$ coupons and polished unidirectionally with 400 grid SiC abrasive papers. This helped in creating some surface defects which are likely to assist in nucleation and growth of fibers during autoclaving. Coupons were rinsed in deionized (DI) water and dried in air. A small bucket-shaped reaction vessel designed and fabricated in the laboratory was used to conduct the hydrothermal reactions. The Ti coupons were placed in a bucket containing $20 \mathrm{~mL}$ of hydrogen peroxide ( $30 \%$ aqueous $\mathrm{H}_{2} \mathrm{O}_{2}$, Fisher Scientific, Waltham, MA, USA). The bucket was placed inside the main stainless steel autoclave, and the entire assembly was sealed. The reaction was carried out at $80^{\circ} \mathrm{C}\left(\right.$ ramp rate of $\left.3^{\circ} / \mathrm{min}\right)$ for $1 \mathrm{~h}$. After the reaction was complete, the coupons were rinsed in DI water under sonication, dried in air, and heated in a split tube furnace (Lindberg Minimite, Asheville, NC, USA) at $700^{\circ} \mathrm{C}$ for $1 \mathrm{~h}$ with a ramp rate of $1 \% \mathrm{~min}$.

2.2. Hydrothermal Processing of $\mathrm{TiO}_{2}$-Coated Ti Plates. The Ti plates from Henkel Corporation (referred to as "Henkel plates" hereafter) had a thin film of $\mathrm{TiO}_{2}$ deposited on them by a patented aqueous plasma electrodeposition (PED) process in which the Ti substrate is made the anode and titanium-bearing compounds in solution are deposited and cured in situ by the plasma glow at the surface [2]. In a typical PED process, a pulsed DC voltage $(240 \mathrm{~V})$ was applied for $10 \mathrm{~ms}$ on and $30 \mathrm{~ms}$ off at a current density of approximately $1500 \mathrm{~A} / \mathrm{m}^{2}$. This results in very adherent titania coatings on the $\mathrm{cp}$ Ti substrates. The as-received Henkel plates were cut into $6 \mathrm{~mm} \times 6 \mathrm{~mm}$ pieces and cleaned in $0.1 \mathrm{M} \mathrm{HCl}$ (Fisher Scientific, Waltham, MA, USA, purity $37.5 \%$ ) for $2 \mathrm{~min}$ followed by rinsing in DI water and acetone, respectively, and air drying. Prior to autoclaving, the Henkel coupons were heated at $800^{\circ} \mathrm{C}$ for $4 \mathrm{~h}$ in static air at a ramp rate of $10^{\circ} / \mathrm{min}$. Retaining one for XRD and SEM analysis, the remaining coupons were chemically etched in $40 \%$ HF (Alfa-Aesar, MA, USA) solution for $10 \mathrm{~s}$ followed by rinsing in acetone and air drying. The heat-treated Henkel plates were subjected to autoclaving in $5 \mathrm{M} \mathrm{NaOH}$ (Fisher Scientific, Waltham, MA, USA) for $2 \mathrm{~h}$ at $100^{\circ} \mathrm{C}$ at a ramp rate of $3 \% \mathrm{~min}$. After the reaction was complete, the autoclaved coupons were washed and sonicated in acetone twice for $2 \mathrm{~min}$.

2.3. Anodization of Ti Plates and Wires. Mohapatra et al. [3] have reported a method of creating $\mathrm{TiO}_{2}$ nanotubes on 0.2$\mathrm{mm}$-thick titanium foil by anodization in a mixture of $0.5 \mathrm{M}$ $\mathrm{H}_{3} \mathrm{PO}_{4}$ and $0.14 \mathrm{M} \mathrm{NaF}$ solution at $20 \mathrm{~V}$ under sonication. In our work, we used a mixture of $0.5 \mathrm{M} \mathrm{H}_{3} \mathrm{PO}_{4}$ (Fisher Scientific, MA, USA) and 0.14 M HF (Alfa-Aesar, MA, USA) instead. Also, 2-mm-thick cp Ti plate instead of foil was used, and the voltage was maintained at $21 \mathrm{~V}$. Sonication ensured that anodization took place evenly across the entire plate. In order to study the change in the quality of the oxide film formed on the surface, anodization was systematically carried out for 1, 2, and $4 \mathrm{~h}$. Furthermore, one Pt wire on either side of the $\mathrm{Ti}$ plate was used to ensure that both sides were anodized. After each run, the anodized plate was thoroughly rinsed in DI water followed by chemical etching in a mixture of ethanol and $40 \% \mathrm{HF}$ ( $5 \mathrm{~mL}$ each) for $5 \mathrm{~s}$ and washing again with DI water. Ti wires $(1.024 \mathrm{~mm}$ in thickness) were also used in place of the Ti plate, in order to approximate the appropriate conditions required to produce the titania nanotubes. The Ti wires were anodized for 1,2 , and $4 \mathrm{~h}$ as well in a $0.5-\mathrm{M} \mathrm{H}_{3} \mathrm{PO}_{4}+0.14 \mathrm{M} \mathrm{HF}$ mixture at a voltage of $21 \mathrm{~V}$. An identical procedure was repeated with the actual implant specimen later. Figure 1 shows the schematic of the setup used in this research.

All the autoclaved and anodized samples were characterized by structural, microstructural, and quantitative analyses using X-ray diffraction (XRD- PANalytical X'Pert Pro MPD), Philips XL30FEG SEM or Hitachi S-4800 High-Resolution SEM, attached with the accessories capable of performing energy-dispersive spectroscopy (EDS) as well. 


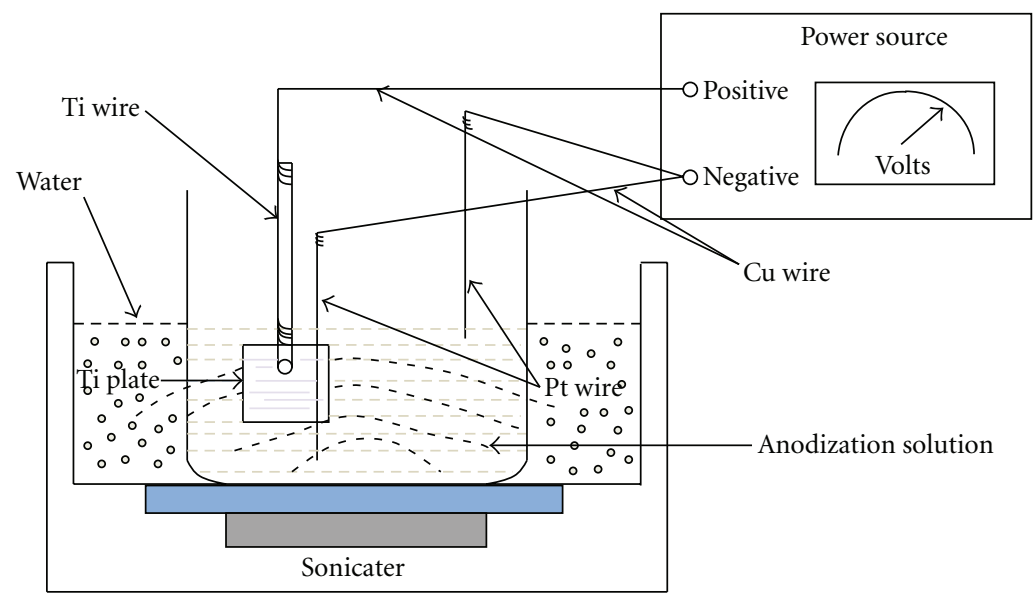

FIgURE 1: Schematic of the anodization setup.

2.4. Preparation of the Escherichia coli (E. coli) Culture. The Escherichia coli \#23724 bacteria were obtained in freezedried form (American Type Culture Collection, Manassas, VA, USA). The dry pellet was rehydrated in $2 \mathrm{~mL}$ of a super broth containing $32 \mathrm{~g}$ tryptone, $20 \mathrm{~g}$ yeast extract, and $5 \mathrm{~g}$ $\mathrm{NaCl}$ (all from Fisher Scientific, Waltham, MA, USA) per liter of aqueous solution made with ultra pure water with a conductivity of $5.5 \times 10^{-8} \mathrm{~S}-\mathrm{cm}$. The super broth solution was sterilized in an autoclave at $121^{\circ} \mathrm{C}$ for $10 \mathrm{~min}$ at $18 \mathrm{psi}$, followed by cooling to room temperature $\left(21^{\circ} \mathrm{C}\right)$ prior to storage in a refrigerator at $5^{\circ} \mathrm{C}$.

The rehydrated E. coli was diluted with $100 \mathrm{~mL}$ of super broth and placed in a sterilized $250 \mathrm{~mL}$ flask. Sterilization was carried out by autoclaving the flask at $122^{\circ} \mathrm{C}$ for $20 \mathrm{~min}$ at 18 psi followed by drying for additional $20 \mathrm{~min}$. The suspension was incubated in a shaker at $37^{\circ} \mathrm{C}$ for $12 \mathrm{~h}$. For the restorage of the E. coli, the solution was spun down in a centrifuge until a pellet formed below a clear solution. The solution was decanted and pellet recovered, to which $10 \mathrm{~mL}$ of $10 \%$ glycerol (Fisher Scientific) solution of super broth was added to suspend the pellet again. The suspension was transferred to Eppendorf tubes and stored in a freezer at $-80^{\circ} \mathrm{C}$.

2.5. Bacterial Growth. For the bacterial growth, $100 \mathrm{~mL}$ of super broth was inoculated with a sterile $10 \mu \mathrm{L}$ loop (Fisher Scientific), followed by agitation at $150 \mathrm{rpm}$ for $12 \mathrm{~h}$ until the bacteria culture reached the stationary phase. To determine the cell concentration, optical density at $600 \mathrm{~nm}$ was measured using a Perkin Elmer Multilabel Counter (Model Victor 3 1420) in solutions of various dilution of E. coli.

2.6. Staining of Bacteria. For the staining purposes, E. coli suspension containing $2.58 \times 10^{8}$ cells $/ \mathrm{mL}$ was used. It was diluted with $100 \mu \mathrm{L}$ of ultrapure water. Live/Dead BacLight Bacterial Viability Kits (Invitrogen, Carlsbad, CA, USA) provide a novel two-color fluorescence assay of bacterial viability that is useful for diverse bacterial genera. In this work, SYTO 9 and propidium iodide stains ( $1 \mu \mathrm{L}$ of each) were used. The E. coli was left in complete darkness for $15 \mathrm{~min}$ at $21^{\circ} \mathrm{C}$ to complete the staining.

In order to photoactivate the Ti plates and wires (against the $E$. coli suspension) onto which titania structure was created, an IR laser $(\lambda=808 \mathrm{~nm}$; power $=1 \mathrm{~W}$; www.freaklasers.com) was used. It should be pointed out that this IR laser is different from the IR flashlight used in our previous work [1] for activating the $\mathrm{TiO}_{2}$ nanofibers. The main reason for changing the source from IR flashlight (for fibers) to the IR laser (for films) is that the intensity of the beam from the flashlight was not strong enough to activate the $\mathrm{TiO}_{2}$ nanofibers or nanotubes formed on the latter. The focus beam size of the IR laser was adjusted to be about $5 \mathrm{~mm}$ diameter. The spatial confinement of the laser beam allowed the excitement of the titania plate alone while causing low or no direct phototoxicity to the bacteria.

For the purpose of evaluating the bactericidal efficacy of titania films formed on the $\mathrm{Ti}$ plate and/or wire, $40 \mu \mathrm{L}$ of the E. coli broth was pipetted in a petri dish. The IR laser was placed $\sim 1$ inch above the Ti coupon/wire and was turned on for 12 to $30 \mathrm{~s}$. This allowed the titania film to be photoactivated. After irradiation, the plate was placed inside the petri dish containing the E. coli broth. The petri dish was then placed appropriately within the confocal microscope. The activity with respect to the bacterial colony was captured for the next several minutes (up to $\sim 50 \mathrm{~min}$ ). The reason for using the IR laser $(\lambda=808 \mathrm{~nm})$ is owing to its effectiveness in the photoactivation of green fluorescent proteins [4]. After several iterations, it was found that excitation by the IR laser for 12 to $30 \mathrm{~s}$ was adequate for causing effective bacterial death. Since the majority of bactericidal experiments using titania photocatalyst to date have employed a UV source [5-9], one set of data was created by using a handheld UV light source $(\lambda=365 \mathrm{~nm}$; Spectroline, model ENF-260C, Westbury, NY, USA) for ready comparison of the results. In the case of UV exposure, excitation duration was varied between $3 \mathrm{~s}$ and up to $20 \mathrm{~min}$.

2.7. In-situ Image Analysis. In order to view the fluorescence given off by these stains, the dish containing titania 


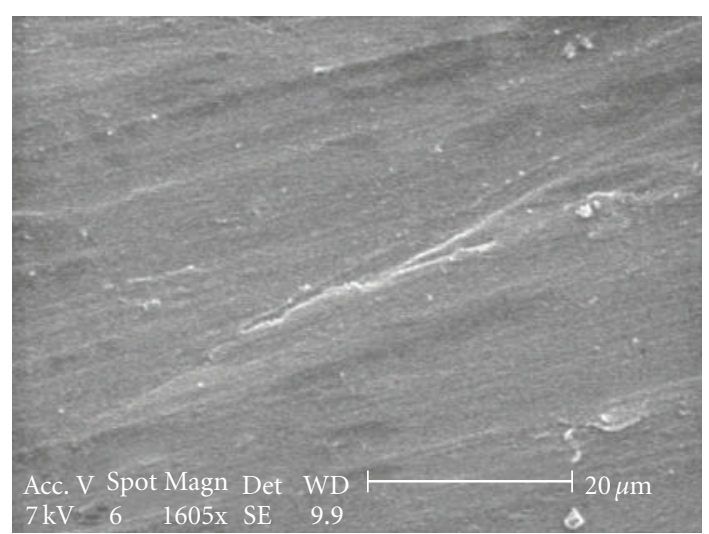

(a)

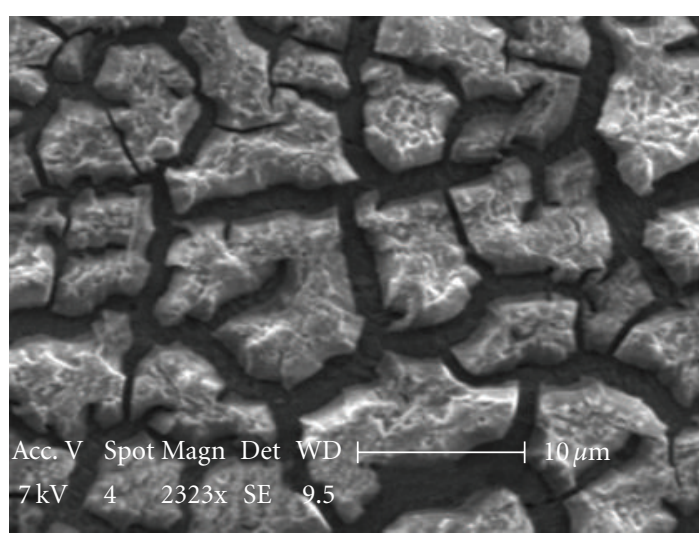

(b)

FIGURE 2: SEM images of the as-received (a) and autoclaved (b) Ti plates.

plates/wires submerged in the E. coli suspension was positioned centrally in the multiphoton laser scanning confocal microscope (model Leica TCS SP5 MP, Leica Microsystems, Bannockburn, IL, USA). This instrument allows adapting the multiphoton system by optimally choosing from IR to picosecond or femtosecond laser and performing experiments with minimal phototoxicity. The reduced phototoxicity due to spatial confinement of excitation is ideal for living cells, which is crucial for this work in order to establish unequivocally that the observed bactericidal effect is due to the photocatalytic artifact of the titania nanofibers upon excitation and not due to photons alone. Upon photoexcitation, the E. coli stained with SYTO9 fluoresces green and that stained with propidium iodide fluoresces red. The excitation and emission of SYTO9 occurs at 480 and $500 \mathrm{~nm}$, respectively. The excitation and emission of propidium iodide occurs at 490 and $635 \mathrm{~nm}$, respectively.

The survival rate of the microorganism was determined by using the imaging software called ImageJ (image processing and analysis in Java-National Institute of Health, Bethesda, MD, USA). This software allows one to count the bacteria in order to determine the amount of live cells compared to total number of cells.

\section{Results and Discussion}

The titania films grown by various techniques described in the previous section on $\mathrm{Ti}$ coupons, wires, and on implants were characterized by multiple techniques, such as XRD, SEM, elemental mapping, and energy-dispersive spectroscopy (EDS). It should be pointed out that the identification of titania films grown on Ti substrates by hydrothermal processing and anodization, by XRD proved to be challenging; since the oxide coating in each of these cases was very thin and the $\mathrm{X}$-rays penetrated past the $\mathrm{TiO}_{2}$ surface, thereby showing the diffraction pattern of titanium lying beneath. Hence, the XRD patterns are not shown. Collecting XRD patterns on wire samples was also challenging.

\subsection{Microstructural Features of Hydrothermally Produced} Titania Films Created on Ti Substrates. The SEM images of
TABle 1: Semiquantitative compositional analyses of the films formed on Ti coupons autoclaved for $1 / 2$ and $1 \mathrm{~h}$.

\begin{tabular}{lcccc}
\hline \multirow{2}{*}{ Element } & \multicolumn{4}{c}{ Autoclaved at $80^{\circ} \mathrm{C}$ for } \\
& wt.\% & at.\% & wt.\% & at.\% \\
\hline $\mathrm{O}$ & 72.77 & 88.89 & 35.01 & 61.73 \\
$\mathrm{Ti}$ & 27.23 & 11.11 & 64.99 & 38.27 \\
\hline Total & 100 & 100 & 100 & 100 \\
\hline
\end{tabular}

as-received and hydrothermally processed (in $30 \% \mathrm{H}_{2} \mathrm{O}_{2}$ solution at $80^{\circ} \mathrm{C}$ for $1 / 2 \mathrm{~h}$ ) Ti plate are shown in Figure 2.

The elemental mapping in the hydrothermally processed plate with respect to titanium and oxygen shown in Figure 3 is indicative of the formation of oxide film.

Upon varying, the time for autoclaving is increased, the film morphology as well as the elemental concentration in the film also changed, as seen from Figure 4, for Ti coupons autoclaved in aqueous $\mathrm{H}_{2} \mathrm{O}_{2}$ solution at $80^{\circ} \mathrm{C}$ for $1 \mathrm{~h}$. This is corroborated by the fraction of $\mathrm{O}$ and $\mathrm{Ti}$ in the two films, as shown in Table 1.

Evidently, on hydrothermal processing for longer duration, greater oxidation of titanium is facilitated which leads to the increase in oxygen content of the film. The composition of the film obtained after $1 \mathrm{~h}$ of autoclaving at $80^{\circ} \mathrm{C}$ is closer to the stoichiometric titania; theoretically, a film of stoichiometric $\mathrm{TiO}_{2}$ contains 60 wt.\% (33 at.\%) of $\mathrm{Ti}$ and $40 \mathrm{wt. \%}$ (67 at.\%) of O. However, the films formed in either case were found to be amorphous; to be photoactive, titania must be crystalline. Therefore, the $\mathrm{Ti}$ plates hydrothermally processed at $80^{\circ} \mathrm{C}$ for $1 \mathrm{~h}$ were calcined at $700^{\circ} \mathrm{C}$ for $1 \mathrm{~h}\left(\right.$ ramp rate: $\left.1^{\circ} / \mathrm{min}\right)$ after cleaning with DI water under sonication.

3.2. Hydrothermally Treated Henkel Plates. As stated earlier, the Ti coupons from Henkel Corporation (Madison Heights, MI, USA) are coated with a thin film of $\mathrm{TiO}_{2}$ (structurally, brookite [2]). These were heated at $800^{\circ} \mathrm{C}$ for $4 \mathrm{~h}$ in static air at a ramp rate of $10^{\circ} / \mathrm{min}$. A comparison of microstructural 

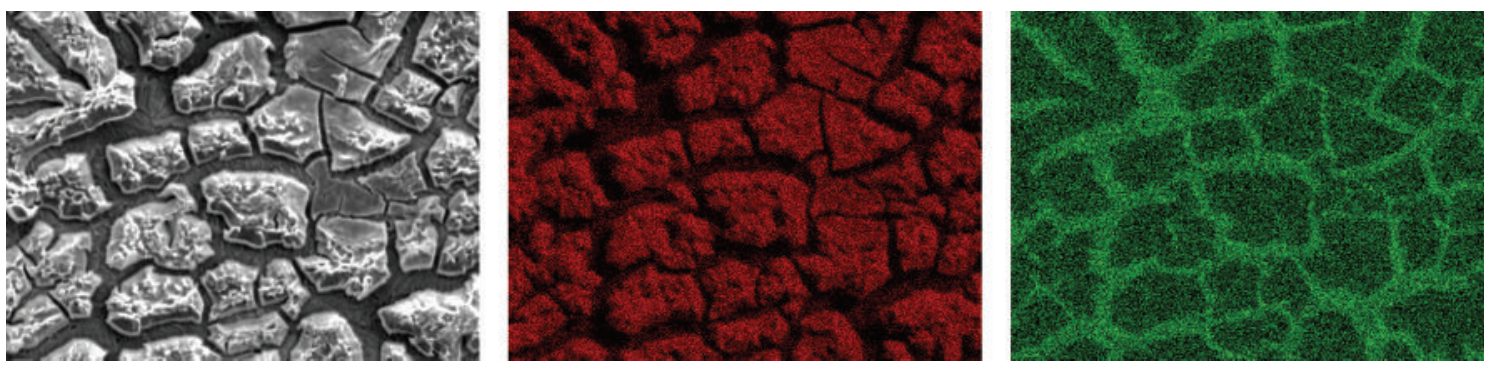

FIGURE 3: Elemental mapping of $\mathrm{TiO}_{2}$ coating on autoclaved Ti plate (O: red, Ti: green).

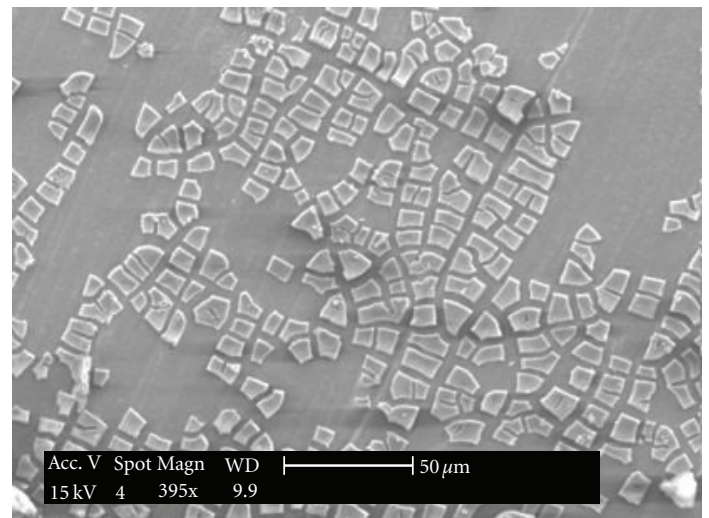

(a)

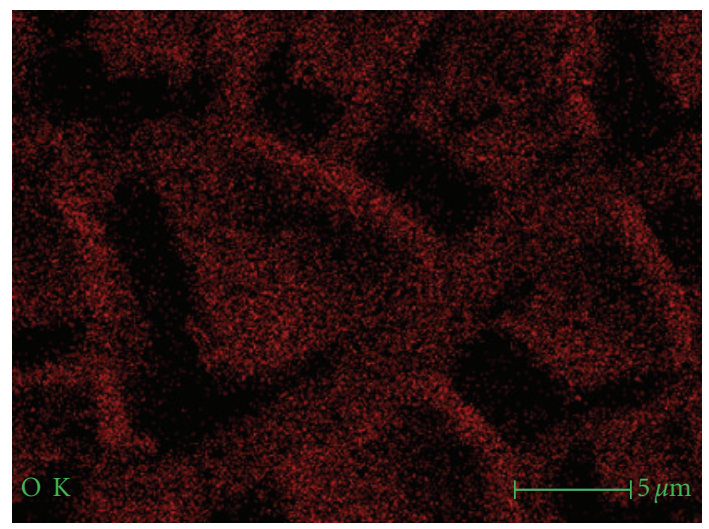

(c)

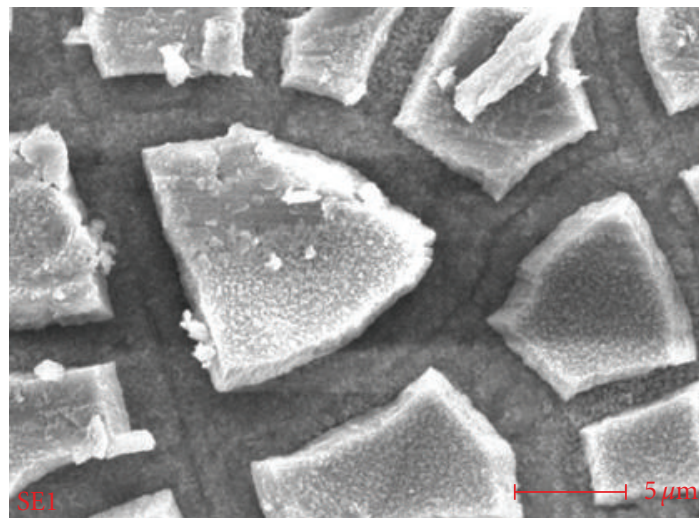

(b)

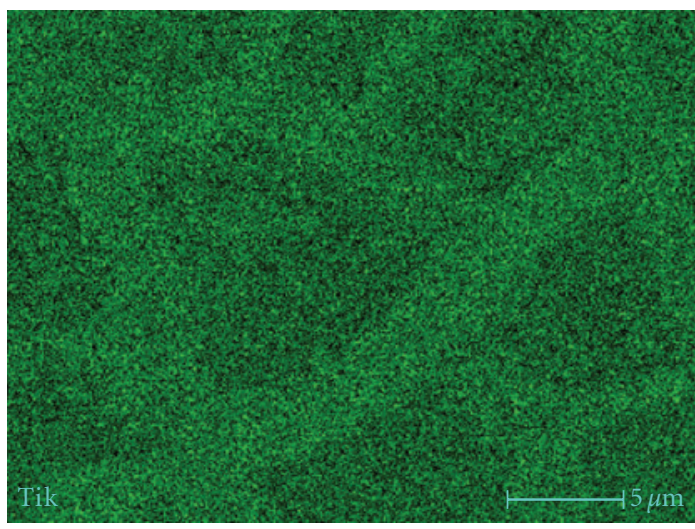

(d)

Figure 4: SEM images and elemental mapping of $\mathrm{TiO}_{2}$ film formed upon autoclaving in $30 \% \mathrm{H}_{2} \mathrm{O}_{2}$ solution at $80^{\circ} \mathrm{C} / 1 \mathrm{~h}(\mathrm{O}$ : red, Ti: green).

features between the as-received and the calcined coupons is shown in Figures 5(a) and 5(b); significant morphological changes could be seen. Quantitative elemental analysis yielded a composition that corresponds to $\mathrm{TiO}_{2}$ within the permissible limits of errors.

Hydrothermal processing has also been employed by others to create $\mathrm{TiO}_{2}$ coating on Ti plates. For example, Wang et al. [10] used hydrothermal treatment of Ti in $10 \mathrm{M}$ $\mathrm{NaOH}$ solution in the temperature range of $140-200^{\circ} \mathrm{C}$ for time periods varying between 2 and $6 \mathrm{~h}$. The autoclaved Ti substrates were soaked in $0.1 \mathrm{M} \mathrm{HCl}$ solution for $12 \mathrm{~h}$ followed by washing with DI water and annealing at 300$500^{\circ} \mathrm{C}$ for $2 \mathrm{~h}$. This helped to create $\mathrm{TiO}_{2}$ nanoarrays.

Zuruzi and MacDonald [11] employed a process called "lift-off technique" to create titania nanoarrays on Ti surface, using aqueous $\mathrm{H}_{2} \mathrm{O}_{2}$ solution. The disadvantage of this procedure is the use of fluoroform, which is known to be a potent greenhouse gas in addition to being toxic. In comparison, the procedure employed in the current work is quite mild where either hydrogen peroxide solution or $5 \mathrm{M}$ $\mathrm{NaOH}$ was used for short duration and at relatively lower temperatures.

3.3. Anodized Ti Substrates. Creation of uniformly distributed nanostructured titania films on Ti plates and wires via anodization in $0.5 \mathrm{M} \mathrm{H}_{3} \mathrm{PO}_{4}+0.14 \mathrm{M}$ HF mixture at a voltage of $21 \mathrm{~V}$ is evidenced from the SEM images shown in Figure 6 for Ti plate and Figure 7 for wire that were anodized for $1 \mathrm{~h}$. 


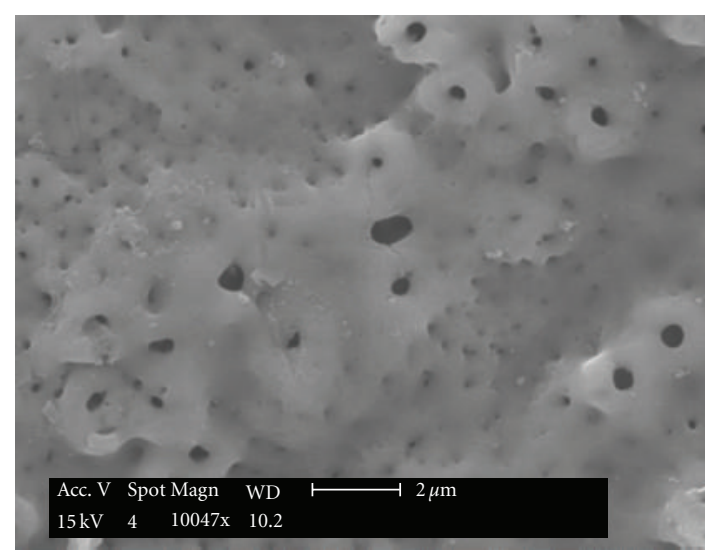

(a)

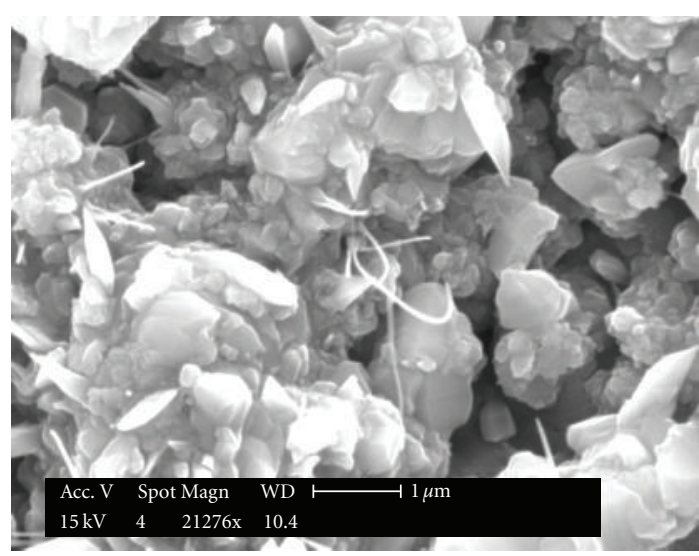

(b)

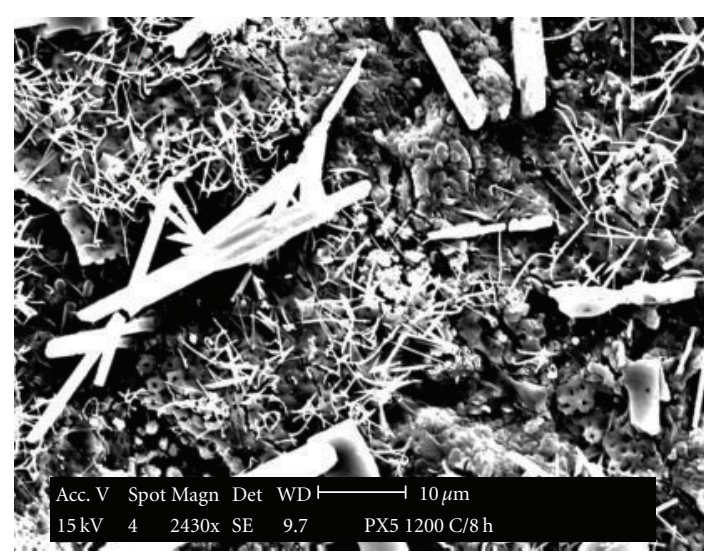

(c)

FIgURE 5: Morphological features in the: (a) as-received, (b) calcined, and (c) autoclaved Henkel plates.

Elemental analyses on different locations of the specimen anodized for $1 \mathrm{~h}$ showed the presence of aluminum in addition to titanium and oxygen. This is due to the fact that commercially pure Ti contains small amount of aluminum; upon anodization, aluminum concomitantly migrates to the surface and also gets oxidized to $\mathrm{Al}_{2} \mathrm{O}_{3}$. This is corroborated by the data shown in Table 2 .

However, as can be seen, the distribution of aluminum is far more widespread in Ti plates (from Titanium Inc.), compared to wire; evidently, in the case of plates, pure $\mathrm{TiO}_{2}$ nanotubes were not generated. We ascribe this difference to the availability of larger surface area in the case of plates that facilitated the migration of aluminum to be more universal than localized. This could be seen by the presence of aluminum as small intertwined rings on top of individual $\mathrm{TiO}_{2}$ nanotubes formed on plates, in Figure 6.

Interestingly, the $\mathrm{Ti}$ plates anodized for $2 \mathrm{~h}$ under identical experimental conditions, showed the development of a consistently uniform nanotubular structure, as can be seen from Figure 8; the nanotubes are about 100-150 nm in diameter and $\sim 300 \mathrm{~nm}$ in height.

Also, from the EDS analysis results collected at random spots on the anodized plate, no evidence of aluminum was found on the film. It is likely that longer anodization leads to the dissolution of aluminum and/or aluminum oxide. This notion was strengthened by the results on anodization experiments carried out for even longer period.

In the case of $\mathrm{Ti}$ plates anodized for $4 \mathrm{~h}$, it was found that the characteristic nanotubular features were totally destroyed. Moreover, in addition to the drastic variation in the morphological features, any titania film, if formed, also was destroyed; EDS analysis confirmed the presence of elemental Ti alone and no aluminum was detected.

This clearly shows that the optimum duration for Ti plate anodization is $2 \mathrm{~h}$ and, therefore, among all the plates, those anodized for $2 \mathrm{~h}$ were used in the bactericidal testing against E. coli.

Mor et al. [12] have reported creating $\mathrm{TiO}_{2}$ nanotubes by anodization using $\mathrm{Ti}$ foil as the anode and $\mathrm{Pt}$ as cathode, in a mixture of $2.5 \mathrm{wt} \% \mathrm{HNO}_{3}$ and $1 \mathrm{wt} \% \mathrm{HF}$ aqueous solution for 1 to $4 \mathrm{~h}$ at temperatures ranging between 5 and $50^{\circ} \mathrm{C}$; the anodization voltage of $20 \mathrm{~V}$ and $50^{\circ} \mathrm{C}$ was reported to yield the best results. Mohapatra et al. [3] reported creating highly ordered nanotubes of $\mathrm{TiO}_{2}$ by anodization of Ti foils $\left(0.2 \mathrm{~mm}\right.$ thick) in a mixture of $0.5 \mathrm{M} \mathrm{H}_{3} \mathrm{PO}_{4}$ and $0.14 \mathrm{M} \mathrm{NaF}$ at room temperature and application of $20 \mathrm{~V}$. In comparison, our modified method was successful in creating nanotubes on $2 \mathrm{~mm}$ thick Ti plates at room temperature. 
TABLE 2: Compositional analyses at different location on the Ti plate and wire anodized for $1 \mathrm{~h}$.

\begin{tabular}{lcccccccc}
\hline \multirow{2}{*}{ Element } & \multicolumn{3}{c}{ Red zone } & \multicolumn{4}{c}{ Anodized Ti wire } \\
& wt.\% & at.\% & wt.\% & at. $\%$ & wt. $\%$ & at. $\%$ & wt. $\%$ & at. $\%$ \\
\hline $\mathrm{O}$ & 16.32 & 29.4 & 21.29 & 34.21 & 37.58 & 62.28 & 26.5 & 51.91 \\
$\mathrm{Ti}$ & 40.28 & 24.24 & 22.18 & 11.9 & 55.05 & 30.48 & 73.5 & 48.09 \\
$\mathrm{Al}$ & 43.39 & 46.36 & 56.54 & 53.88 & 7.37 & 7.24 & 0 & 0 \\
\hline Total & 100 & 100 & 100 & 100 & 100 & 100 & 100 & 100 \\
\hline
\end{tabular}

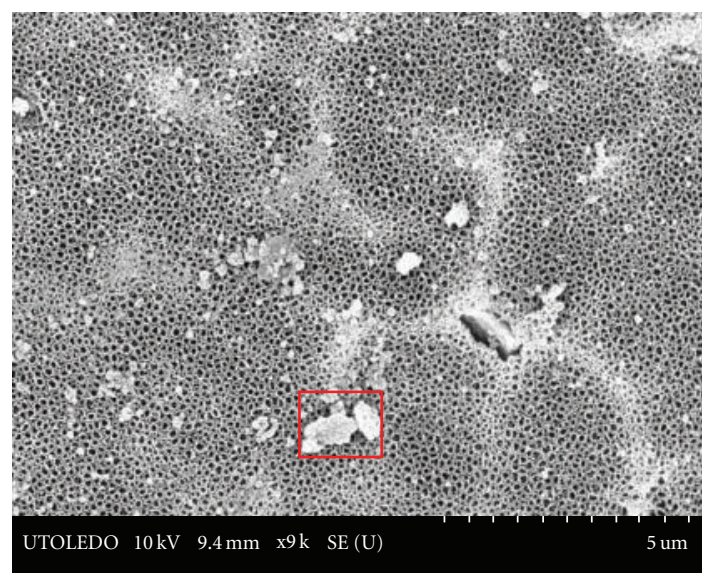

(a)

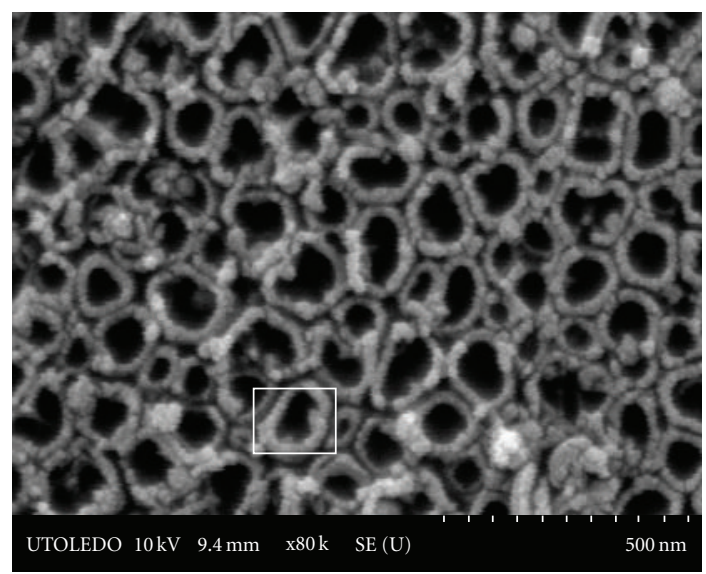

(b)

Figure 6: SEM images of $\mathrm{TiO}_{2}$ nanotubes created on cp Ti plate anodized for $1 \mathrm{~h}$.

3.4. Evaluation of Bactericidal Efficacy. A detailed systematic evaluation protocol was drawn and carried out in order to unequivocally establish that the bacterial necrosis was most effective in the presence of titania films on $\mathrm{cp}$ Ti plates and wires, and that both irradiation and photocatalyst were needed.

Recently, we demonstrated the bactericidal efficacy of pure and Fe-doped titania nanofibers made by electrospinning [1] towards E. coli upon activation by $\mathrm{UV}(\lambda=365 \mathrm{~nm})$, multiphoton IR laser $(\lambda=820 \mathrm{~nm})$ and IR $(\lambda=830 \mathrm{~nm})$. It was also found that the illumination of $E$. coli broth by these radiations alone did not cause bacterial deactivation and necrosis [13]. It should be pointed out that unlike the free-standing fibers which are interconnected by particles whose average size is $30-40 \mathrm{~nm}, \mathrm{cp} \mathrm{Ti}$ and implant coupons used in this work were about $2 \mathrm{~mm}$ thick; even the Ti wire was $1.024 \mathrm{~mm}$ in thickness. Thus, it was imperative that in order to obtain appreciable bacterial mitigation, duration of photoactivation should be somewhat longer than that used in the case of nanofibers [1].

The confocal images of bacterial colonies after exposing the autoclaved or anodized Ti plates and wires to photoactivation by a handheld IR laser $(\lambda=808 \mathrm{~nm})$ for various durations are shown in Figures 9, 10, and 11. Green pixels represent live cells while red pixels are for the dead cells.

The confocal data shown above, led to the conclusion that, among all Ti samples tested with the IR laser, two sets of results were most promising: (i) the Henkel Ti plates autoclaved in $5 \mathrm{M} \mathrm{NaOH}$ at $100^{\circ} \mathrm{C}$ for $2 \mathrm{~h}$, and (ii) the plates from Titanium Inc. that were anodized for $2 \mathrm{~h}$ and chemically etched for $5 \mathrm{~s}$ in $\mathrm{EtOH} / \mathrm{HF}$ mixture. In order to make a realistic comparison of the data collected on IR-activated specimen, parallel experiments were also carried out with UV light exposure on the two plates that worked well with IR beams. The autoclaved Henkel plates were found to be more effective than those anodized for $2 \mathrm{~h}$. These results are shown in Figure 12.

The assessment of bactericidal effects of $\mathrm{TiO}_{2}$ particle irradiated by UV light has been examined by researchers to control bacterial infections in clinical applications. Koseki et al. [14], for example, used a suspension of Staphylococcus aureus of concentration $1 \times 10^{5} \mathrm{cfu} / \mathrm{mL}$ (colony-forming units) in a solution containing $19 \mu \mathrm{g} / \mathrm{mL}$ of $\mathrm{TiO}_{2}$ particles and irradiated them for $1 \mathrm{~h}$ with UV light $\left(1.82 \mathrm{~mW} / \mathrm{cm}^{2}\right)$ in one case and with fluorescent light $\left(80 \mu \mathrm{W} / \mathrm{cm}^{2}\right)$ in the other. It was found that the bacterial survival rate decreased steadily, reaching $9.4 \%$ after exposure to UV and $10.9 \%$ after exposure to fluorescent light.

$\mathrm{Yu}$ et al. [15] have reported the fabrication of Fedoped $\mathrm{TiO}_{2}$ films on stainless steel substrates by dip coating followed by calcination and their use as antibacterial agents for sterilization against Bacillus pumilus. In this case, a suspension of Bacillus pumilus of concentration $1 \times$ $10^{7} \mathrm{cfu} / \mathrm{mL}$ (colony-forming units) was placed onto the $\mathrm{TiO}_{2}$-coated stainless steel plate which was irradiated by a UV lamp (intensity rating $630 \mu \mathrm{W} / \mathrm{cm}^{2} ; \lambda=365 \mathrm{~nm}$ ). Their 


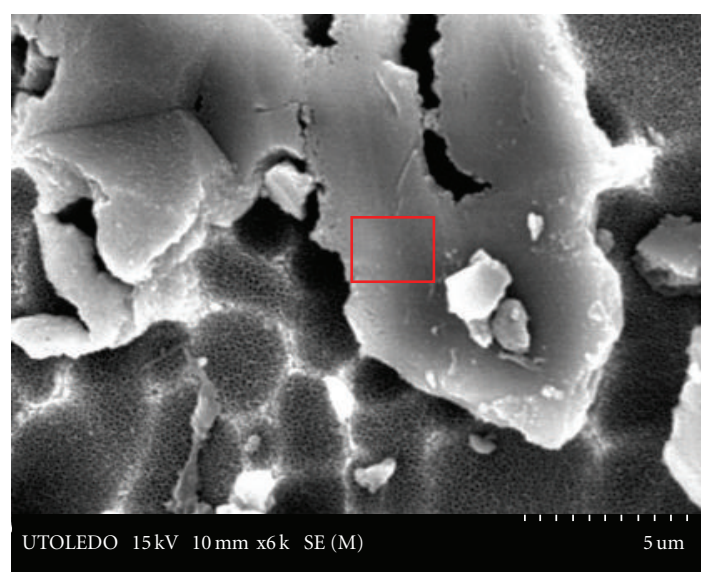

(a)

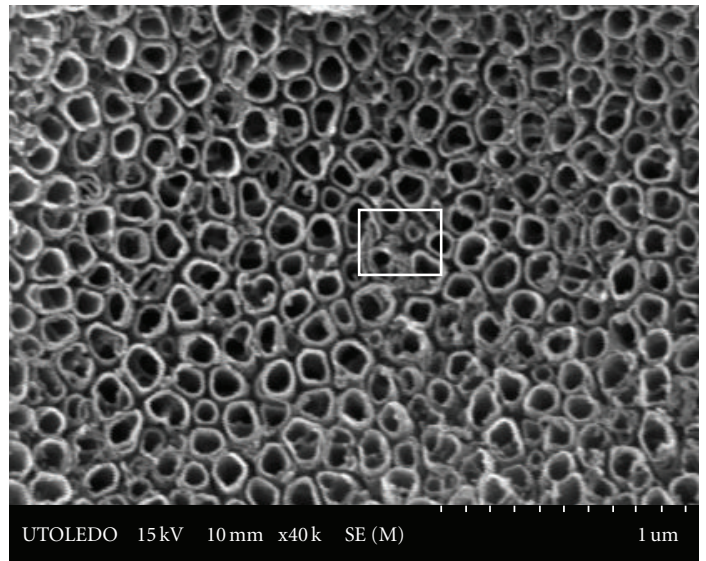

(b)

FIgURe 7: SEM images of $\mathrm{TiO}_{2}$ nanotubes created on cP Ti wire anodized for $1 \mathrm{~h}$.

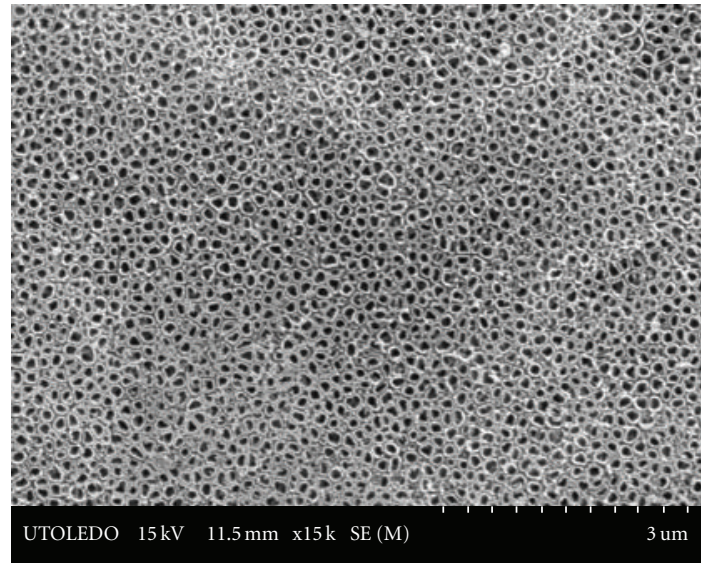

(a)

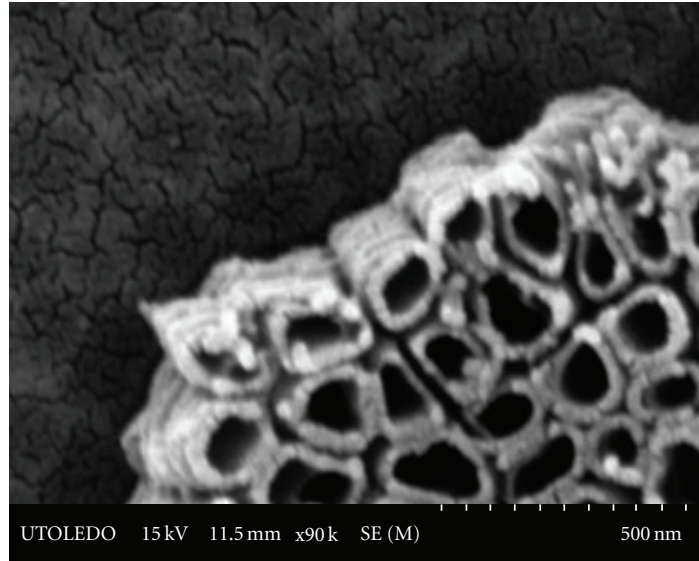

(b)

FIgURE 8: SEM images of the Ti plate anodized for $2 \mathrm{~h}$.

results showed that the active Bacillus pumilus colonies on the titania films subjected to UV illumination decreased by $50 \%$ after $2 \mathrm{~h}$ of exposure.

In a recent work, Oka et al. [5] studied the inhibition of bacterial colonization of methicillin-resistant Staphylococcus aureus (MRSA) suspensions $\left(1 \times 10^{8} \mathrm{cfu} / \mathrm{mL}\right)$ on $\mathrm{TiO}_{2}$ film prepared by direct oxidization of pure titanium substrate. In this case, the titania coating on Ti was created by etching the latter with $5-10 \%$ HF solution followed by soaking in aqueous $\mathrm{H}_{2} \mathrm{O}_{2}$ for 2 days. The MRSA suspension on the implant was exposed to the ultraviolet A (UVA) light for $60 \mathrm{~min}$ and the number of colonizing bacteria was estimated. The bactericidal ability of the photocatalyst became apparent after $60 \mathrm{~min}$, when the bacteria had almost disappeared; only about $7 \%$ bacteria were found alive. The number of colonizing bacteria on photocatalytic pins also decreased significantly in vivo as well. The titania film was found to be quite effective even against resistant bacterial colonization.

Table 3 summarizes the results of the present work and compares them with those reported on bactericidal efficacy of titania nanofibers made via electrospinning [1] and titania powder, using UV radiation and other types of microorganisms. As is well known, the UV radiation has higher photon energy than its IR counterpart. However, calculations based on the intensity of the incident beam and the time of exposure in each case, show that the number of photons incident per unit area during the exposure time is higher in the case of the present work using IR beam. This, in turn, translates into higher efficiency of the IR light compared to UV by several orders of magnitude (photons $/ \mathrm{cm}^{2}$ ), since there are more photons for the time duration in comparison to the UV; this explains why the IR method used in this work, even for the shortest period of exposure, was much more effective than longer exposure by UV in the cases reported in the literature. We believe that the demonstration of the efficacy of IR light towards infection mitigation in terms of biocidal activity of titania is the first of its kind.

From the foregoing discussion, it is clear that a judicious combination of catalytic artifacts of titania and incident 


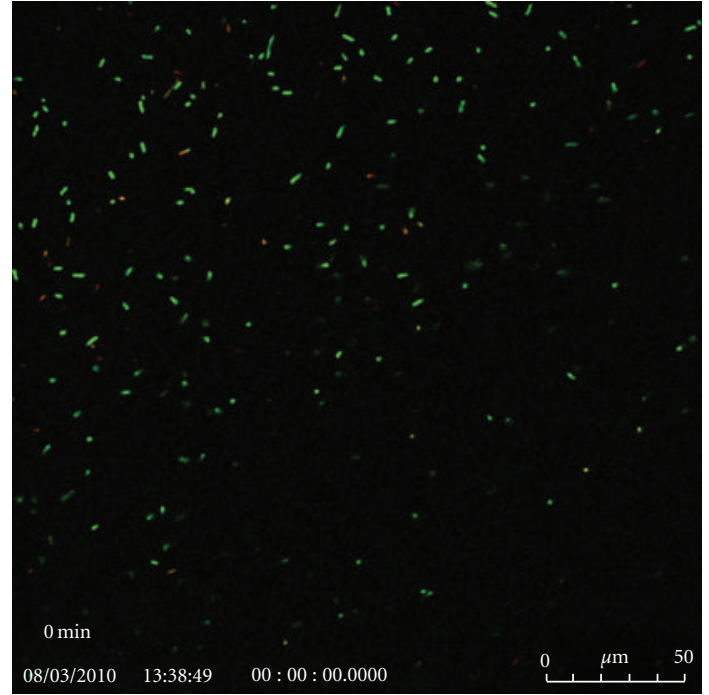

(a)

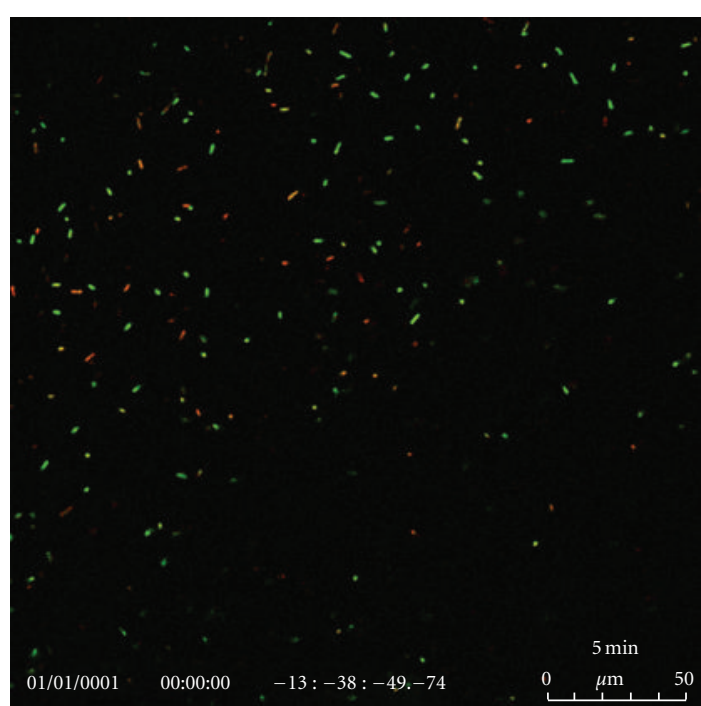

(b)

Figure 9: Confocal images of the bacterial colonies at different times in suspension containing Henkel Ti plate (autoclaved in $5 \mathrm{M}$ NaOH at $\left.100^{\circ} \mathrm{C} / 2 \mathrm{~h}\right)$ and exposed to a handheld IR laser $(\lambda=808 \mathrm{~nm})$ for $30 \mathrm{~s}$.

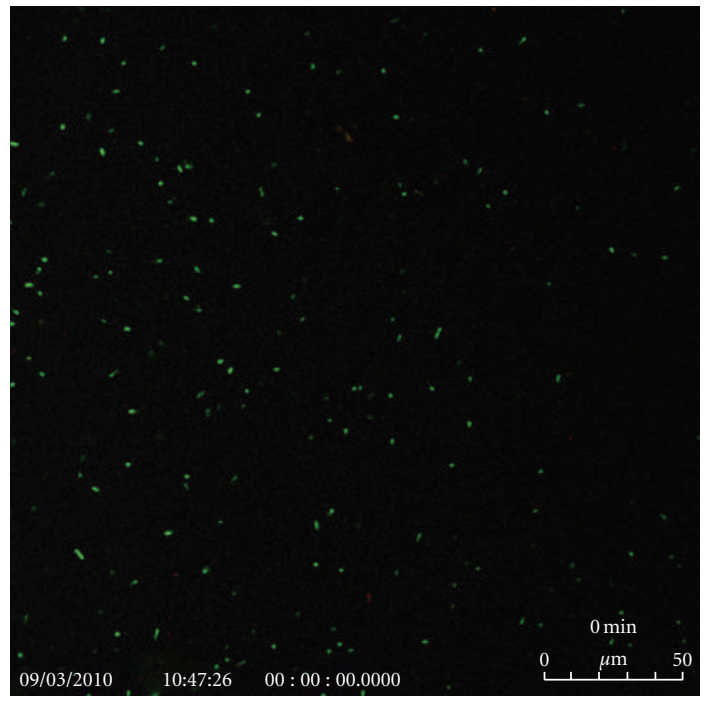

(a)

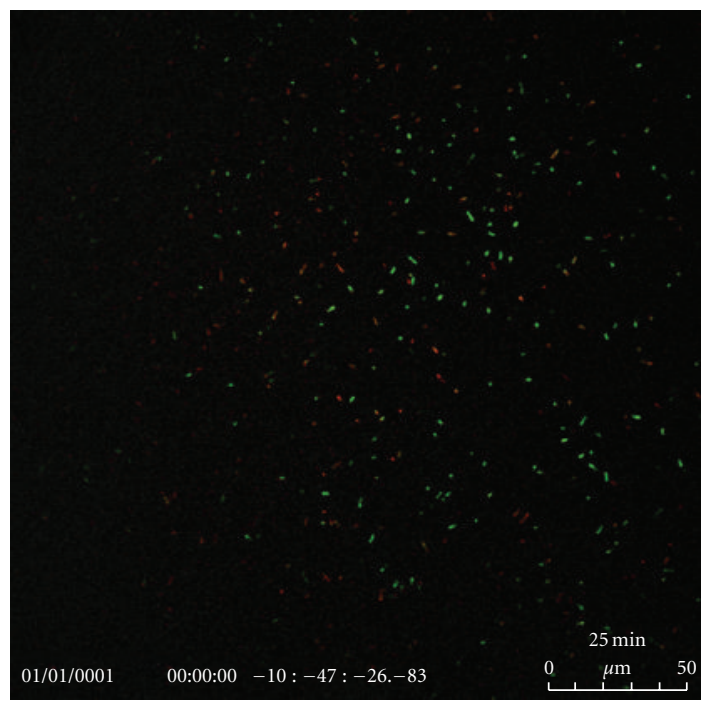

(b)

FIGURE 10: Confocal images of the bacterial colonies at different times in suspension containing Ti plate (Titanium Inc.; anodized for $2 \mathrm{~h}$ and chemically etched in EtOH/HF mixture for $5 \mathrm{~s})$ and exposed to a handheld IR laser $(\lambda=808 \mathrm{~nm})$ for $24 \mathrm{~s}$.

photons is quite effective in inhibiting bacterial colonization. While ultraviolet beam is effective in treating bacterial infection, it however, necessitates longer exposure to be of quantitative value; in some cases, the exposure could last from 20 to $60 \mathrm{~min}$. In comparison, the present work demonstrates that better bactericidal activities were observed with IR exposure for a far shorter duration. Furthermore, combination of novel and benign methodologies of creating titania films and nanotubular configurations with infrared excitation in mitigating colonization is reported for the first time. This opens up the possibility of using an orthopedic implant with photoactive coating irradiated by a very short pulse of an infrared beam, as an infection mitigation device.

It should be pointed out that while $\gamma$-radiations have been used in other processes, the authors are not aware of any with regard to their use in conjunction with titania. Moreover, the gamma rays are a form of ionizing radiation and as such, they pose health hazard. They, like neutrons, are more penetrating, causing diffusive damage to the body tissues (e.g., radiation sickness, increased probability of cancer). External radiation exposure should also be distinguished from internal exposure, due to ingested or 


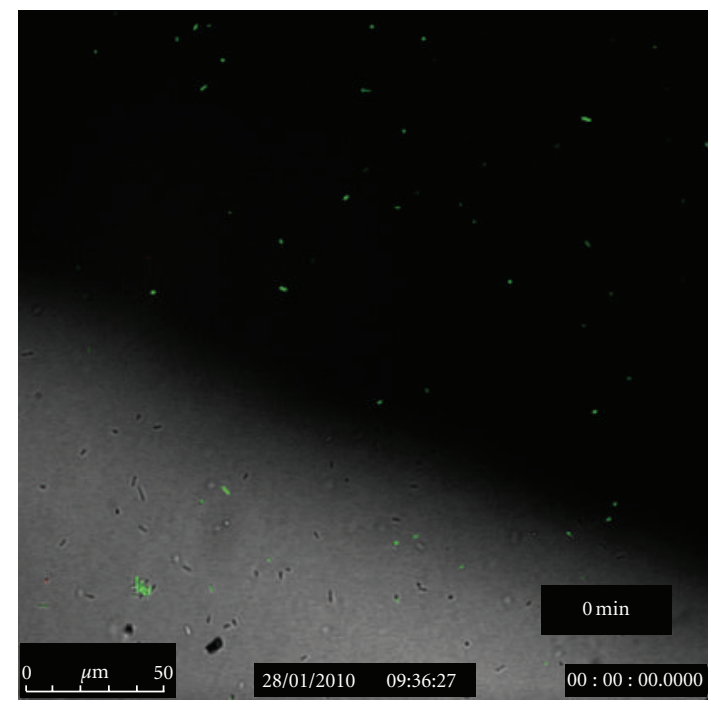

(a)

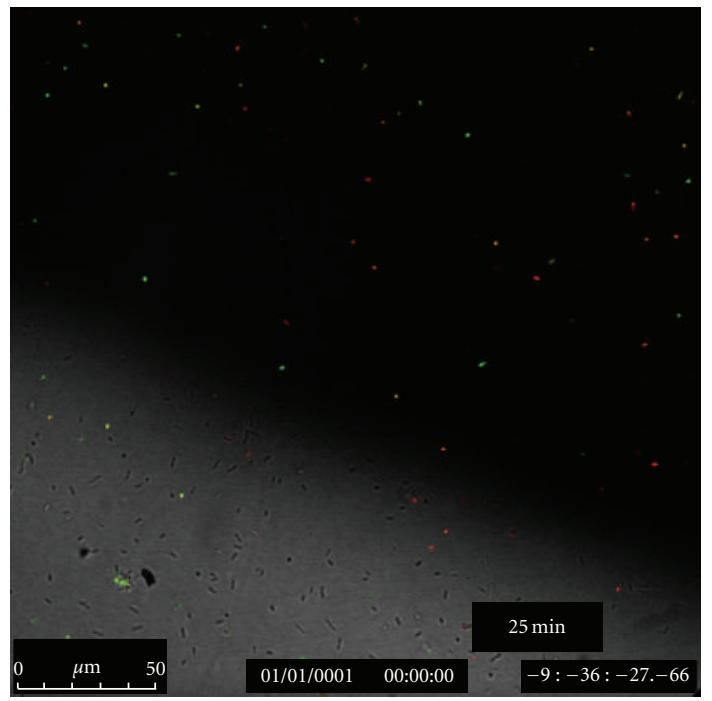

(b)

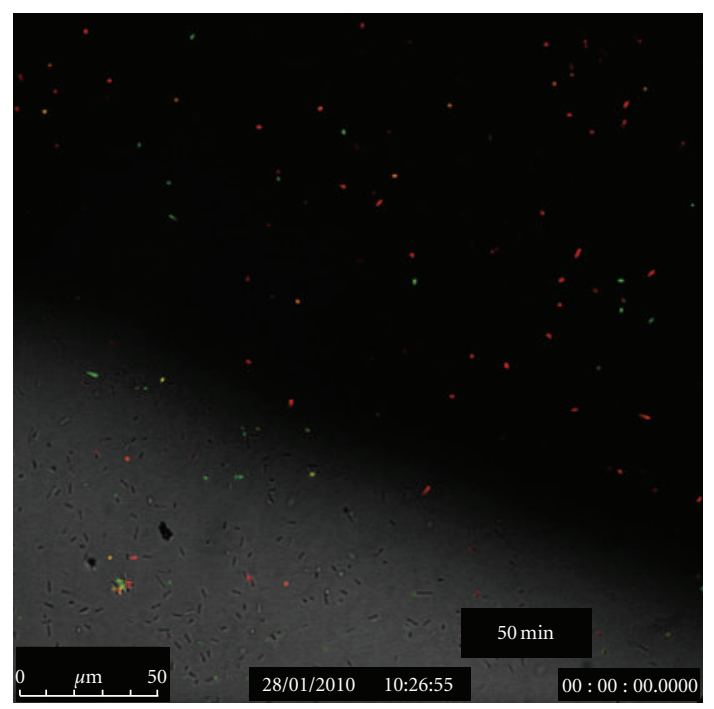

(c)

FIgURE 11: Confocal images of the bacterial colonies at different times in suspension containing Ti wire anodized for $1 \mathrm{~h}$ and exposed to a handheld IR laser $(\lambda=808 \mathrm{~nm})$ for $12 \mathrm{~s}$.

inhaled radioactive substances, which, depending on the substance's chemical nature, can produce both diffuse and localized internal damage.

Consequently, gamma rays would kill the bacteria but also harm the human host from the inside out. On the other hand, the use of an alternative sterilization agent, namely, ethylene oxide (EtO) is not benign: its shortcoming is that it may leave toxic residuals that would cause adverse reactions after implantation. Thus, its efficacy towards bacterial resistance or necrosis is questionable. On the other hand, the energetic photons generated on the photoactivated implants, lead to the generation of free radicals that oxidize and kill the bacteria more efficiently.
This is the first feasibility study on the use of IR radiation on its bactericidal potential. Though the successful implementation of the adopted strategy has been demonstrated, this by no means is an indication that the positive, but nevertheless mediocre, level of necrosis ( $\sim 60-70 \%$ reduction) is acceptable as a final outcome. We recognize and emphasize that more work needs to be done to attain clinically meaningful levels of reduction which requires orders of magnitude reduction in viability. These practical goals could be achieved by optimizing the proposed method by, for instance, somewhat longer IR radiation exposure using a radiation source of higher strength (power), and so forth. 

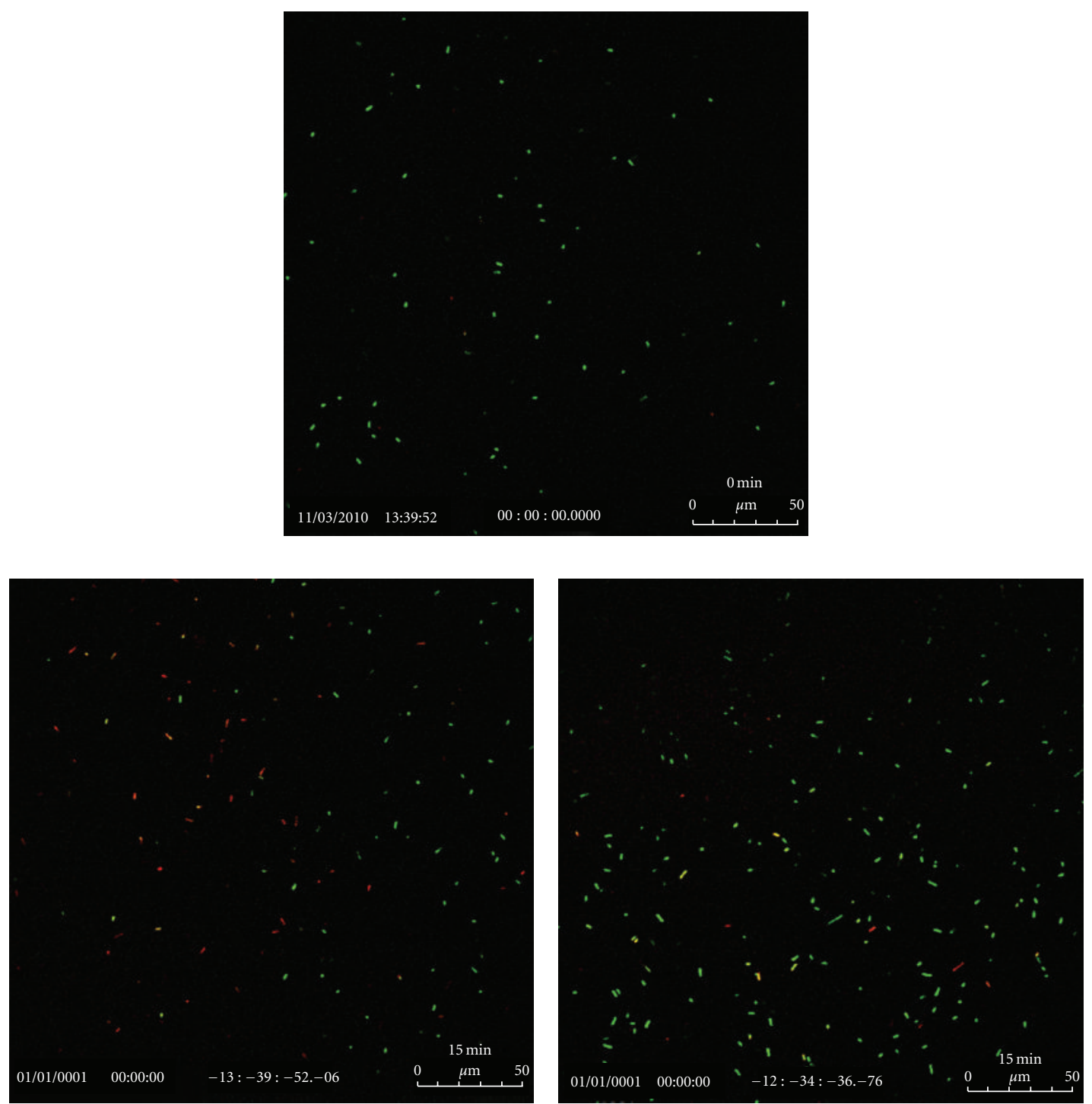

FIGURE 12: Confocal images of the bacterial colonies after $15 \mathrm{~min}$ in suspension containing: (right side) Henkel Ti plate autoclaved in $5 \mathrm{M}$ $\mathrm{NaOH}$ at $100^{\circ} \mathrm{C} / 2 \mathrm{~h}$ and (left side) Ti plate (Titanium Inc.; anodized for $2 \mathrm{~h}$ and chemically etched for $5 \mathrm{~s}$ in EtOH/HF) exposed to UV beam for $20 \mathrm{~min}$.

With regard to the next steps in terms of evaluating the titania-coated implants, we plan to gauge the effectiveness (efficacy and/or toxicity) of the material on the underlying wounds or infections. Experiments are in progress to examine the efficacy of titania against $S$. aureus, since it is a BSL2 gram-positive bacterium while E. coli is a gram-negative BSL1 agent. The gram-positive bacterium has stronger membrane and is likely to be more resistant to the reactive free radicals created with the photoexcitation of titania. At this juncture, it is worth pointing out that it is likely that the $\mathrm{TiO}_{2}$ micro/nanocoatings could lead to discontinuities with the potential to reduce the fatigue strength of the devices coated with $\mathrm{TiO}_{2}$. We will attempt to address these issues, by doing coated-implant evaluations as per the ASTM standards, in subsequent studies.

\section{Conclusions}

Nanostructured titania coatings were created by mild and benign techniques of hydrothermal processing and anodization on titanium substrates. The films were characterized thoroughly for their structural integrity and microstructural features. Their efficacy for the inhibition of bacterial colonization of $E$. coli was evaluated by irradiating with a handheld IR laser and UV beams for durations between $12 \mathrm{~s}$ and $30 \mathrm{~min}$. The confocal microscopic results demonstrated that IR exposure for short duration was quite effective in bactericidal activities.

To expand the application of titania coatings on implants for wound disinfection, assessing their effect on the bacterial spores, commonly accepted by the medical device 
TABLE 3: Summary of the results and comparison with the literature.

\begin{tabular}{|c|c|c|c|c|c|c|c|c|}
\hline Bacteria & Light source & $\lambda(\mathrm{nm})$ & $\begin{array}{c}\text { Exposure } \\
\text { time }\end{array}$ & $\begin{array}{l}\text { Intensity } \\
\left(\mathrm{W} / \mathrm{cm}^{2}\right)\end{array}$ & $\begin{array}{l}\text { Photon } \\
\text { energy }(\mathrm{J})\end{array}$ & Photon/area ${ }^{\ddagger}$ & $\begin{array}{l}\text { Survival } \\
\text { rate (\%) }\end{array}$ & Reference \\
\hline $\begin{array}{l}\text { Staphylococcus } \\
\text { aureus }\end{array}$ & UV & 352 & $60 \mathrm{~min}$ & $1.82 \times 10^{-3}$ & $\begin{array}{c}5.647 \times \\
10^{-19}\end{array}$ & $1.16 \times 10^{19}$ & 9.4 & $\begin{array}{c}\text { Koseki et al. } \\
{[14]}\end{array}$ \\
\hline Bacillus pumilus & UV & 365 & $120 \mathrm{~min}$ & $630 \times 10^{-6}$ & $\begin{array}{c}5.446 \times \\
10^{-19}\end{array}$ & $8.33 \times 10^{18}$ & $\leq 50$ & $\begin{array}{c}\text { Yu et al.\# } \\
\text { [15] }\end{array}$ \\
\hline $\begin{array}{l}\text { Methicillin- } \\
\text { resistant } \\
\text { Staphylococcus } \\
\text { aureus (MRSA) }\end{array}$ & UVA & 365 & $60 \mathrm{~min}$ & $1.1 \times 10^{-3}$ & $\begin{array}{c}5.446 \times \\
10^{-19}\end{array}$ & $7.27 \times 10^{18}$ & 7 & $\begin{array}{l}\text { Oka et al. }{ }^{\#} \\
{[5]}\end{array}$ \\
\hline Escherichia coli & IR/MP & 820 & $3 \mathrm{~s}$ & $2 \times 10^{6}$ & $\begin{array}{c}2.424 \times \\
10^{-19}\end{array}$ & $2.48 \times 10^{25}$ & 10 & $\begin{array}{l}\text { Azad et al. } \$ \\
{[1]}\end{array}$ \\
\hline Escherichia coli & IR/laser & 808 & $30 s$ & 5 & $\begin{array}{c}2.460 \times \\
10^{-19}\end{array}$ & $6.10 \times 10^{20}$ & 60 & This work $\$$ \\
\hline Escherichia coli & UV & 365 & $20 \mathrm{~min}$ & $350 \times 10^{-6}$ & $\begin{array}{c}5.466 \times \\
10^{-19}\end{array}$ & $7.68 \times 10^{17}$ & 60 & This work $\$ \$$ \\
\hline
\end{tabular}

${ }^{\ddagger}$ Incident photons per unit area during exposure time are obtained by multiplying the ratio of intensity $\left(\mathrm{W} / \mathrm{cm}^{2}\right)$ and photon energy $(\mathrm{J})$ with the time of exposure (s).

\#Titania powder.

\$Titania nanofibers.

\$ Titania coating on cp Ti.

community, such as Bacillus pumilus and Staphylococcus aureus is under progress.

\section{Acknowledgments}

The authors wish to express their gratitude to Ms. Tamara Phares of the Bioengineering Department, Dr. Andrea Kalinoski of the Advanced Microscopy and Imaging Center (Department of Surgery, Health Science Campus), and Mr. Robert Kinner of the Chemical Engineering Department for their assistance in various stages of this work. Financial support from DePuy Spine (Johnson and Johnson, MA, USA) is also gratefully acknowledged. The authors greatly appreciate the constructive comments and valuable suggestions made by the referee to improve the merit of the work reported here.

\section{References}

[1] A.-M. Azad, R. Hershey, S. Ali, and V. Goel, "Bactericidal efficacy of electrospun pure and Fe-doped titania nanofibers," Journal of Materials Research, vol. 25, no. 9, pp. 1761-1770, 2010.

[2] A. M. Azad, S. Dolan, and S. A. Akbar, "Development of agile titania sensors via high-temperature reductive etching process (HiTREP()): I. Structural reorganization," International Journal of Applied Ceramic Technology, vol. 5, no. 5, pp. 480-489, 2008.

[3] S. K. Mohapatra, M. Misra, V. K. Mahajan, and K. S. Raja, "A novel method for the synthesis of titania nanotubes using sonoelectrochemical method and its application for photoelectrochemical splitting of water," Journal of Catalysis, vol. 246, no. 2, pp. 362-369, 2007.

[4] Y. Chen, P. J. MacDonald, J. P. Skinner, G. H. Patterson, and J. D. Müller, "Probing nucleocytoplasmic transport by two-photon activation of PA-GFP," Microscopy Research and Technique, vol. 69, no. 3, pp. 220-226, 2006.

[5] Y. Oka, W. C. Kim, T. Yoshida et al., "Efficacy of titanium dioxide photocatalyst for inhibition of bacterial colonization on percutaneous implants," Journal of Biomedical Materials Research-Part B, vol. 86, no. 2, pp. 530-540, 2008.

[6] D. B. Hamal and K. J. Klabunde, "Synthesis, characterization, and visible light activity of new nanoparticle photocatalysts based on silver, carbon, and sulfur-doped $\mathrm{TiO}_{2}$," Journal of Colloid and Interface Science, vol. 311, no. 2, pp. 514-522, 2007.

[7] P. C. Maness, S. Smolinski, D. M. Blake, Z. Huang, E. J. Wolfrum, and W. A. Jacoby, "Bactericidal activity of photocatalytic $\mathrm{TiO}_{2}$ reaction: toward an understanding of its killing mechanism," Applied and Environmental Microbiology, vol. 65, no. 9, pp. 4094-4098, 1999.

[8] S. R. Bhattarai, N. Bhattarai, HO. K. Yi, P. H. Hwang, D. I. Cha, and H. Y. Kim, "Novel biodegradable electrospun membrane: scaffold for tissue engineering," Biomaterials, vol. 25, no. 13, pp. 2595-2602, 2004.

[9] J. Zeng, X. Xu, X. Chen et al., "Biodegradable electrospun fibers for drug delivery," Journal of Controlled Release, vol. 92, no. 3, pp. 227-231, 2003.

[10] W. Wang, H. Lin, J. Li, and N. Wang, "Formation of titania nanoarrays by hydrothermal reaction and their application in photovoltaic cells," Journal of the American Ceramic Society, vol. 91, no. 2, pp. 628-631, 2008.

[11] A. S. Zuruzi and N. C. MacDonald, "Facile fabrication and integration of patterned nanostructured $\mathrm{TiO}_{2}$ for microsystems applications," Advanced Functional Materials, vol. 15, no. 3, pp. 396-402, 2005.

[12] G. K. Mor, O. K. Varghese, M. Paulose, K. Shankar, and C. A. Grimes, "A review on highly ordered, vertically oriented $\mathrm{TiO}_{2}$ nanotube arrays: fabrication, material properties, and solar energy applications," Solar Energy Materials and Solar Cells, vol. 90, no. 14, pp. 2011-2075, 2006.

[13] R. Hershey, Development of titania nanofibers and films for the mitigation of wound infection, M.S. thesis, Department 
of Chemical Engineering, University of Toledo, Toledo, $\mathrm{OH}$, USA, 2010.

[14] H. Koseki, K. Shirai, T. Tsurumoto et al., "Bactericidal performance of photocatalytic titanium dioxide particle mixture under ultraviolet and fluorescent light: an in vitro study," Surface and Interface Analysis, vol. 41, no. 10, pp. 771-774, 2009.

[15] J. C. Yu, W. Ho, J. Lin, H. Yip, and P. K. Wong, "Photocatalytic activity, antibacterial effect, and photoinduced hydrophilicity of $\mathrm{TiO}_{2}$ films coated on a stainless steel substrate," Environmental Science and Technology, vol. 37, no. 10, pp. 2296-2301, 2003. 


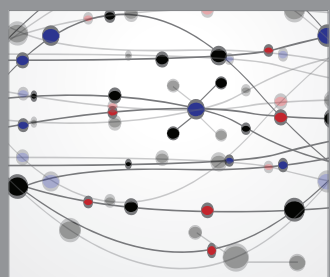

The Scientific World Journal
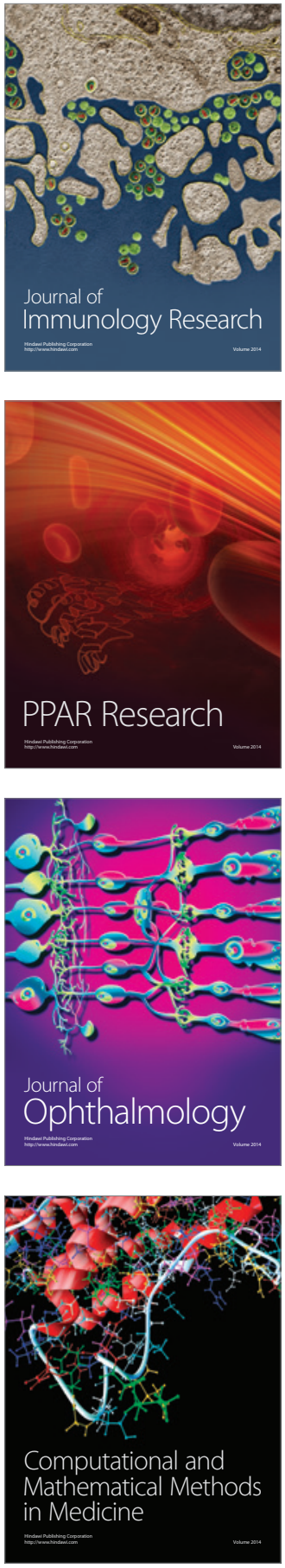

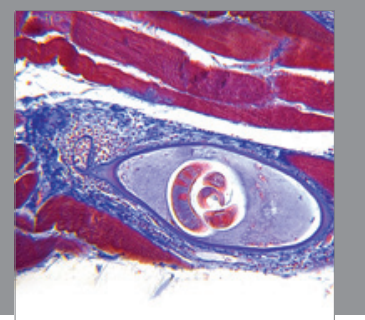

Gastroenterology

Research and Practice
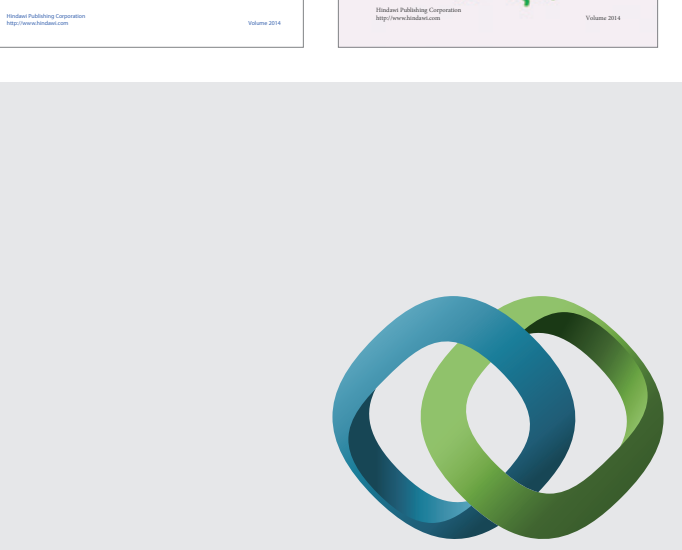

\section{Hindawi}

Submit your manuscripts at

http://www.hindawi.com
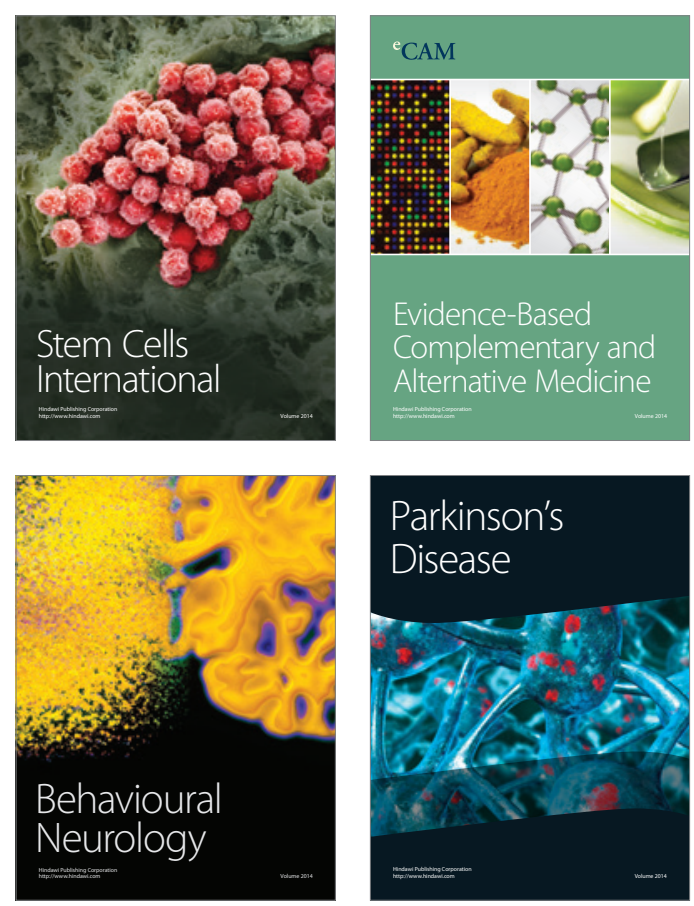

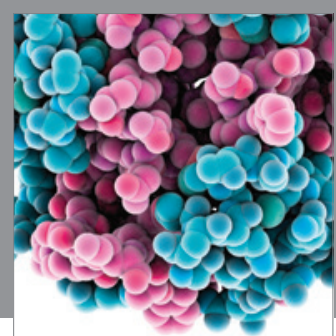

Journal of
Diabetes Research

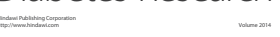

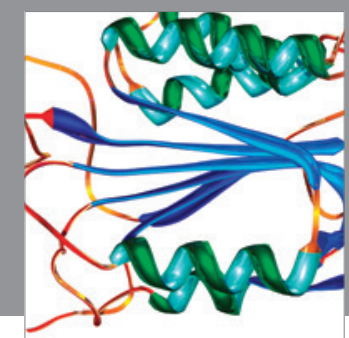

Disease Markers
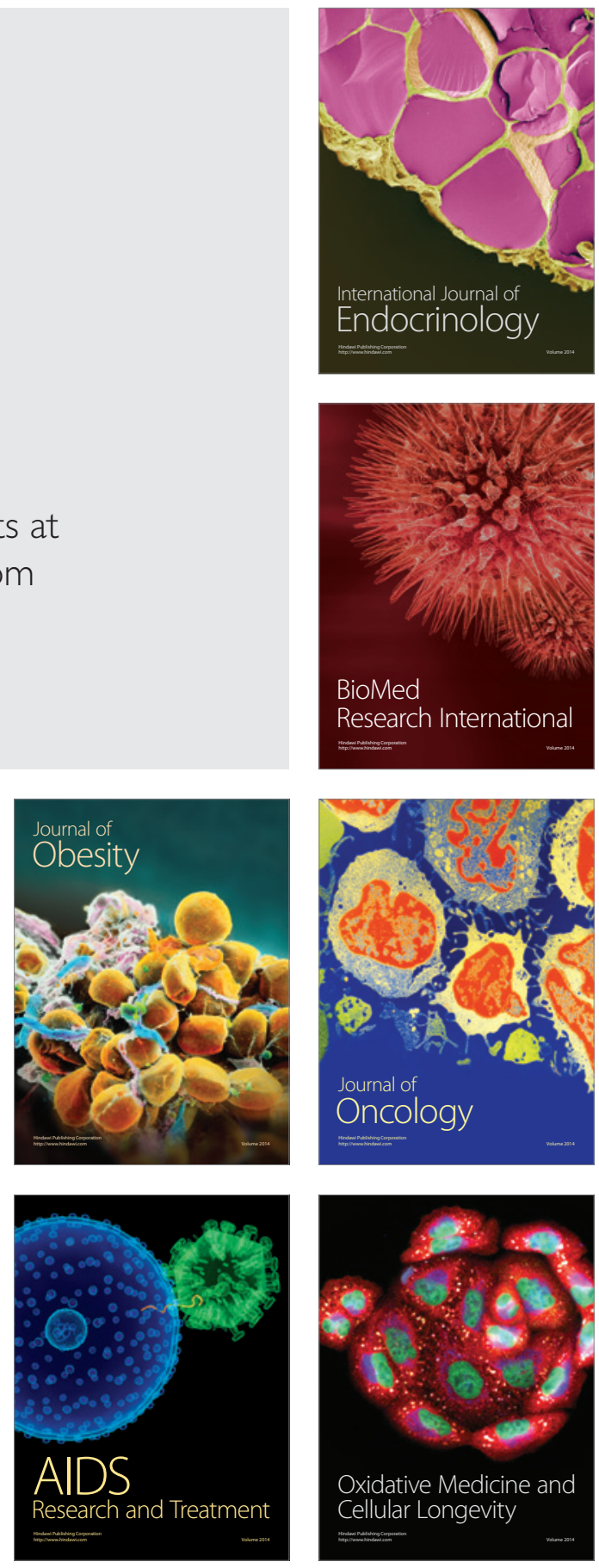